\title{
PROBLEMS AND PROSPECTS OF UNIVERSITY-INDUSTRY INTERACTION
}

\author{
Vladimir Bredikhin $^{1 *}$, N.E. Ovchinnikova ${ }^{2}$, O.P. Ovchinnikova ${ }^{3}$, Tatiana Kolmykova ${ }^{1}$ \\ ${ }^{1}$ Southwest State University, Kursk \\ ${ }^{2}$ Moscow school of management SKOLKOVO \\ ${ }^{3}$ Peoples' Friendship University of Russia (RUDN University)
}

The main goal of the presented research paper is to find solutions to existing problems in the field of interaction between the university and the industrial sector. This goal is achieved by solving the following tasks:

1. analyze of the evolution of university-industry interaction;

2. analyze of the situation in the field of university and business / industry interaction;

3. focusing on the need for universities - industry cooperation and identifying key barriers in their interaction;

4. consideration of formats for university and business / industry interaction.

The objectives of this article are achieved through a review of the existing literature, a synthesis of the necessary knowledge about the interaction of the university and the industrial sector, the analysis of the need for interaction, key barriers, and interaction formats to formulate proposals that improve cooperation and identify the most effective ways of partnership. This analysis covers the following documents: information and analytical sources, research projects of predecessors, data from international research organizations, and historical documents.

Key words: University-industry integration, The triple helix, Higher education, Regional development

\section{INTRODUCTION}

The economy of the Russian Federation continues to be in a crisis and its formation as an independent unit directly depends on the development of the research and technological components, especially in the conditions of a knowledge-based economy. The leading supplier of innovative products are universities. Universities need to respond in a timely manner to external challenges and to point out to advance not only at the regional level, but also to go beyond it. However, as soon as the university starts to work in this direction, higher educational institutions encounter significant obstacles in the way of establishing partnership with innovative enterprises, as well as they face problems in the development of innovation activities within the university and beyond.

The key issues which universities facing can be identified by the following points:

- the majority of research conducted at the university level doesn't meet the requirements of industry and the real sector;

- the majority of R\&D is developed in the framework of grants that are not aimed at further commercializing or introducing them into production;

- researchers aren't interested in developing working innovations (which will be applicable and commercialized);

- entrepreneurial spirit in universities isn't stimulated in the field of research and innovation.
As for the gap in the representation of innovations by industry and universities, they are faced with a fundamental misunderstanding on both sides, which significantly reduces the interest of actors to each other and inhibits the development of scientific and technological progress. In the Address of the President of the Russian Federation to the Federal Assembly of March 1, 2018, special attention was paid to the development of technologies, knowledge and competencies. Crucial role in this process plays a university, ranging from career-oriented work and ending with fundamental applied research and development. Russian President Vladimir Putin noted that technological development should be lean on a strong base of fundamental science, as well as the need to enter a fundamentally new level in the research infrastructure. It was noted the need to create powerful scientific and educational centers that would integrate the capabilities of universities, academic institutions, and high-tech companies. That is why this research is a significant development, relevant for the modern stage of economic development.

\section{EVOLUTION OF UNIVERSITY-INDUSTRY INTERACTION IN RUSSIA}

The time line of interaction between university and industry in Russia presented on the Figure 1. It can be noted that this form of interaction originates in the pre-revolutionary era. The pre-revolutionary period is characterized by the emergence of factory science and some large enterprises had advanced laboratories and design bu- 


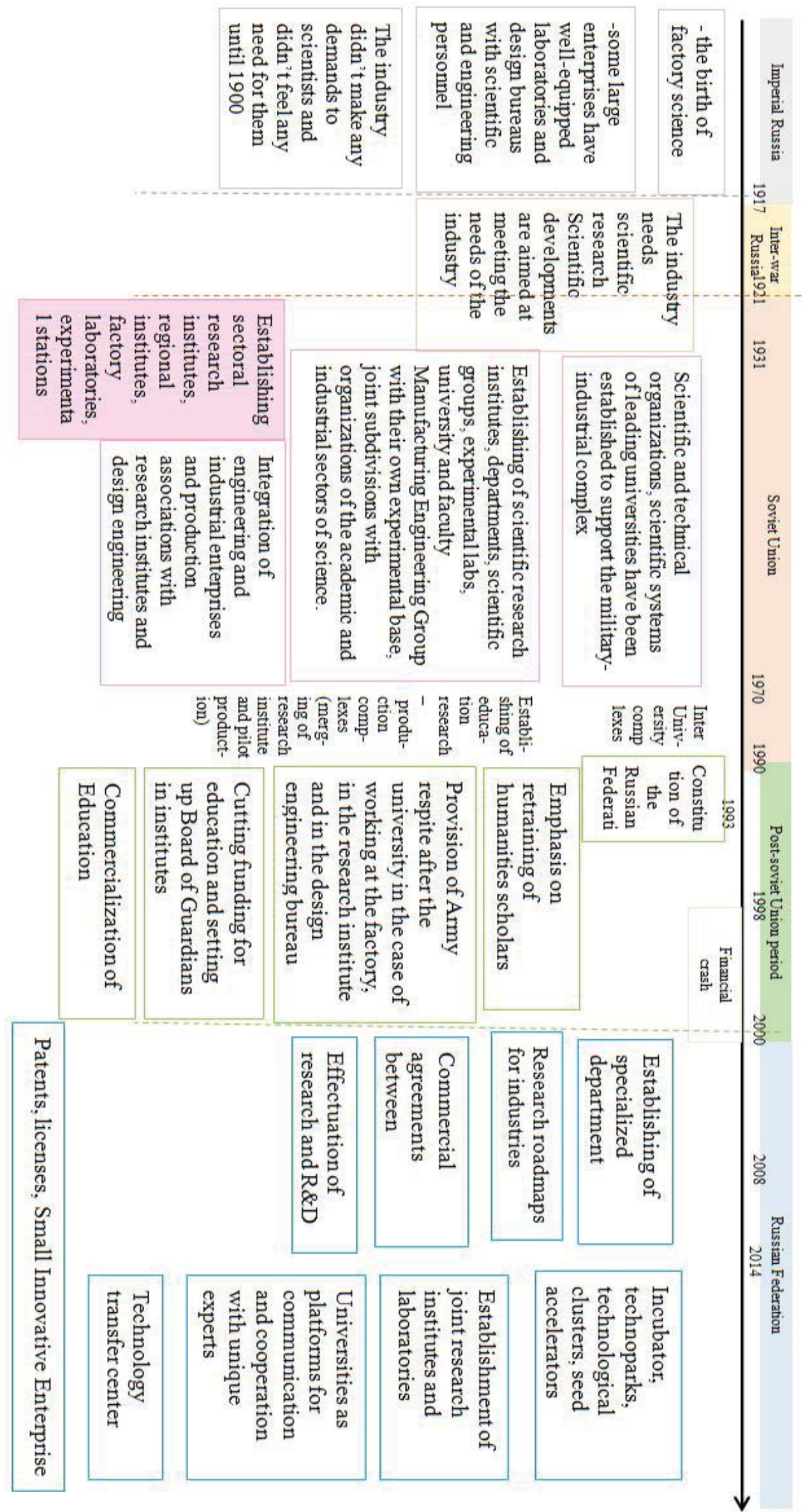

Figure 1: Evolution of university-industry interaction in Russia 
reaus, which were provided by scientific and engineering personnel. At this historical period, there was no strong research field, and Russian science had a large gap form the European one. In recent decades, before the revolution, scientific research has begun to be more practical and started to apply in industry, medicine and agriculture. [1]

During the civil war and the first decades after it, much of the research works were focused on meeting the needs of the industry. In 1931 are appeared the first scientific research institutes, sectoral research institute at higher educational institutions, regional institutes, and also factory laboratories, experimental stations. The period from 1931 to 1955 is characterized by the creation of a military and civilian scientific system, which are reflected in the military-industrial complex and civil science. This stage is the most breakthrough in the context of universities and industry interaction. The military-industrial science was mostly classified and was held within the walls of specialized military institutes and didn't apply to civilian products. The most interesting period from the transparency and effectiveness point of view can be considered the civilian part of scientific developments. Such developments have been carried out in several sectors:

\section{Academic sector}

It included the Academy of Sciences of the USSR and sectoral research academies. This period was characterized by the development of scientific and technical centers, polygons, pilot production facilities, etc. The academic sector mostly cooperated with line ministries and departments, carried out work to improve and modernize production facilities or production process to order specific industrial enterprises. One of the distinctive qualities of the academic sector was the inclusion in the implementation of state programs for the development of the necessary design solutions for their use in industry

\section{University sector}

Period from 1931 to 1955 is characterized by the development of institutions and industry interaction. The first scientific research institutes, departments, scientific groups, experimental farms, problem and branch laboratories was appeared in this period. On the base of higher educational institutions, design and technology bureaus are being created. They have their own experimental base in their arsenal. The joint departments with the academic and branch science sectors are gaining popularity. Closer to the 70th years there are territorial intercollegiate complexes, allowing to create a research base even in the absence of necessary specialists in the initiating institute for the first time. As a rule, these complexes were formed on the base of customized complex scientific and technical tasks and united various scientific teams for their implementation.

\section{Factory sector}

This sector had relationships with institutes and universities in terms of scientific development and training. The factory sector became the base for the unification of the engineering and technical divisions of industrial enterprises and research institutes and design bureaus. A distinctive feature of this format of interaction was that all of the above scientific units were on an independent balance in the structure of industrial enterprises.

\section{Industry sector}

Industry sector was focused on applied research and development. As a rule, R\&D was carried out by subordinate research organizations under special control by departmental structures.

Summing up this period (1931-1955), we can note a number of common factors that have become forerunners of further development of universities and industry interaction: [2]

- the importance of new technologies in industry was growing;

- $\quad$ country faced with the problem of knowledge lack in the modern research and technologies;

- the absence of specialists leads to the economic stagnation;

- the government understood the importance of cooperation between universities and industry, especially in research and specialist preparation;

- the war period showed the lack of new technologies and weapons which led to the new way of research support;

- the post war period characterized by the need to restore and renew production and without good research this mission would be a failure.

A distinctive feature of this period was the orientation on strong scientific developments in the field of the defense industry to the detriment of the civil sector development. The allocated financial resources for scientific and technical development didn't meet the demands of the economy of that time and lag behind from the foreign countries in the development of scientific research aimed at the consumer market.

After the collapse of the USSR, which officially dates from December 25, 1991, universities are beginning to experience one of the most difficult periods in their history. Back in 1987, before the collapse of the USSR, all scientific organizations were transferred to self-sufficiency, which significantly changed their model of interaction with industry and others actors. Along with the growing need to conclude contracts with industry for scientific research, the material and technical base wasn't updated, which was reflected both in the lack of enterprises interest to invest financial resources and in the capacity of institutions to fulfill the orders of industry.

Until 1993, universities and institutions were in a state of uncertainty due to a turning point in the country. In 1993, the Constitution of the Russian Federation was adopted, after which significant changes became evident not only in the education system, but also in the country as a whole. A drastic change in the ideology of education has 
led to the need for retraining of humanities teachers and to give less attention to the development of partnerships with industry. Industry at the time was also in a crisis and funding for research and development couldn't be included in its expenditure items. Approximately, in 1995, in order to support industry at the state level, a postponement from the army after the university was indicated to those candidates who would go to work to the industry, to research institutes and design bureaus. The first and second Chechen wars, as well as the 1998 crisis, seriously complicated the development of science and university cooperation with industry. In 1998, the financing of the education sector was reduced by $12 \%$, the wages of university workers became minimal, and production, experiencing difficult financial times refused to interact with universities. At that time, the industry didn't see the benefits of investing in development funds on the basis of institutes and universities, thereby weakening this industry and the relationship between scientific organizations and enterprises.

After 2000, a new reform of education was adopted and it didn't have the expected effect. Up to 2011 there was a delay in technological modernization of science and insufficient funding of research developments. At present, it can be noted that the situation stimulates the introduction of new conceptual solutions to solve the existing problems. In the report "Monitoring of the economic situation in Russia", which was published on January 2018, says that more people with higher education are leaving Russia nowadays and this has a crucial influence on technological progress. [3] According to the data presented in the report "Qualified migration in Russia: the balance of losses and acquisitions" [4], the total number of educated Russian emigrants is about 800 thousand people and this number is growing each year. According to the Federal State Statistics Service, the number of high-performance jobs is reduced annually by 900,000 units and simultaneously, there are lots of head hunters trying to find the right person for their job position. Such imbalance on the labor market leads to the serious problems in economics and technological development. The share of domestic expenditure on research and development in GRP is reduced by $0.04 \%$ annually. The domestic expenditure on research and development fluctuate within $1 \%$ of the gross domestic product in the whole of the Russian Federation. The share of organizations that carried out technological innovations in the reporting year in the total number of organizations surveyed as a whole for the Russian Federation is reduced by approximately $0.7 \%$ annually from $8.3 \%$. During the period from 1990 to 2011, the number of researchers fell by about 2.6 times, which negatively affected the country's research potential. A serious impetus in the development of relations between universities and industry was the period of the sanctions regime in 2014, which allowed cooperation and interaction of universities and industry to enter a new stage in order to obtain new performance results and modernize existing processes.

\section{CURRENT SITUATION IN R\&D IN RUSSIA}

The number of active patents fell by 9,496 units in 2016 [5]. According to BCG, the deficit of qualified personnel in Russia will be 10 million people until 2025 [6]. According to the Federal State Statistics Service in 2016, the number of graduates of bachelors, specialists, masters is 972400 people. From the data listed above, we see the gap between reproduction of professionals the needs of the market, taking into consideration the fact that some of the highly professionals are leaving abroad. This situation is also because the level of education in universities that lags behind the demands of the market and advanced research trends. Table 1 shows the number of organizations engaged in research and development and, unfortunately, their number isn't sufficient to fully reproduce new knowledge and train professional staff. [7] Universities and industry interaction is based on the fundamental factor that can be named "university research and development involvement", which will be useful and important for industry. According to the World Bank, the specific intensity of research and development in foreign countries is much higher than in the Russian Federation (Figure 2). [8]

The specific R\&D expenditures in the Russian Federation are low relative to other countries (Figure 3 ). The financing of science from the federal budget for the last year decreased by $36,670.5$ million rubles.

Expenses for civilian science from the federal budget as of 2017 amount to 402722.3 million rubles to the expenditures of the federal budget for the last year decreased by $0.36 \%$ and amounted to $2.45 \%$, and to the gross domestic product for the last year decreased by $0.06 \%$ and amounted to $0.47 \%$. [9] These figures demonstrate the need for a reorientation of the university research base on alternative sources of financing, especially to increase the importance of cooperation with industry and business sectors.

Despite the fact that the intensity of research activities remains low, the increase of domestic expenditure on re-

Table 1: The number of organizations performing research and development

\begin{tabular}{|c|c|}
\hline Type of organization & $\begin{array}{c}\text { Change in the } \\
\text { number during the 10 } \\
\text { years (units) }\end{array}$ \\
\hline R\&D organizations & -376 \\
\hline Desing organizations & -178 \\
\hline $\begin{array}{c}\text { Reseacrh project } \\
\text { organizations }\end{array}$ & -32 \\
\hline Pilot plants & +13 \\
\hline Higher education institutes & +562 \\
\hline $\begin{array}{c}\text { Industries, having scientific } \\
\text { research, design and } \\
\text { engineering divisions }\end{array}$ & +108 \\
\hline Others & +313 \\
\hline
\end{tabular}




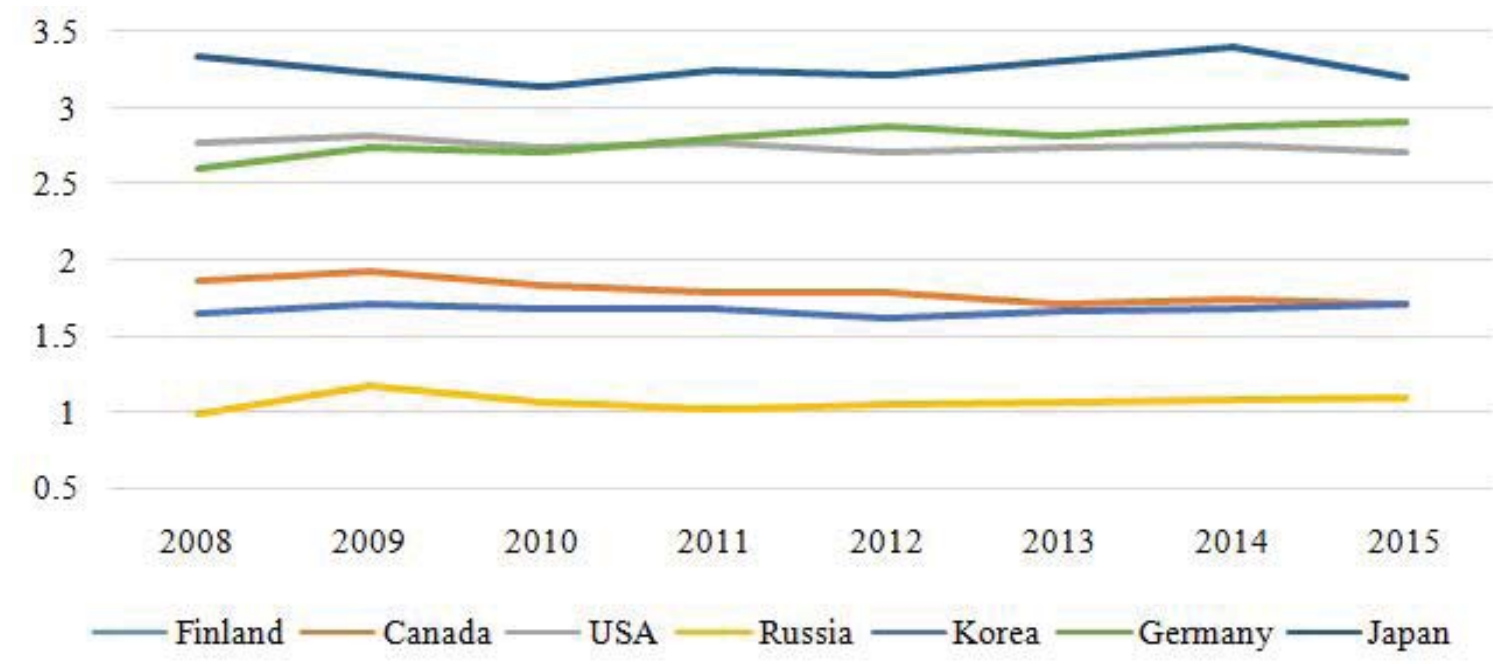

Figure 2: Specific R\&D intensity in comparison with the Russian Federation (\% of GDP)

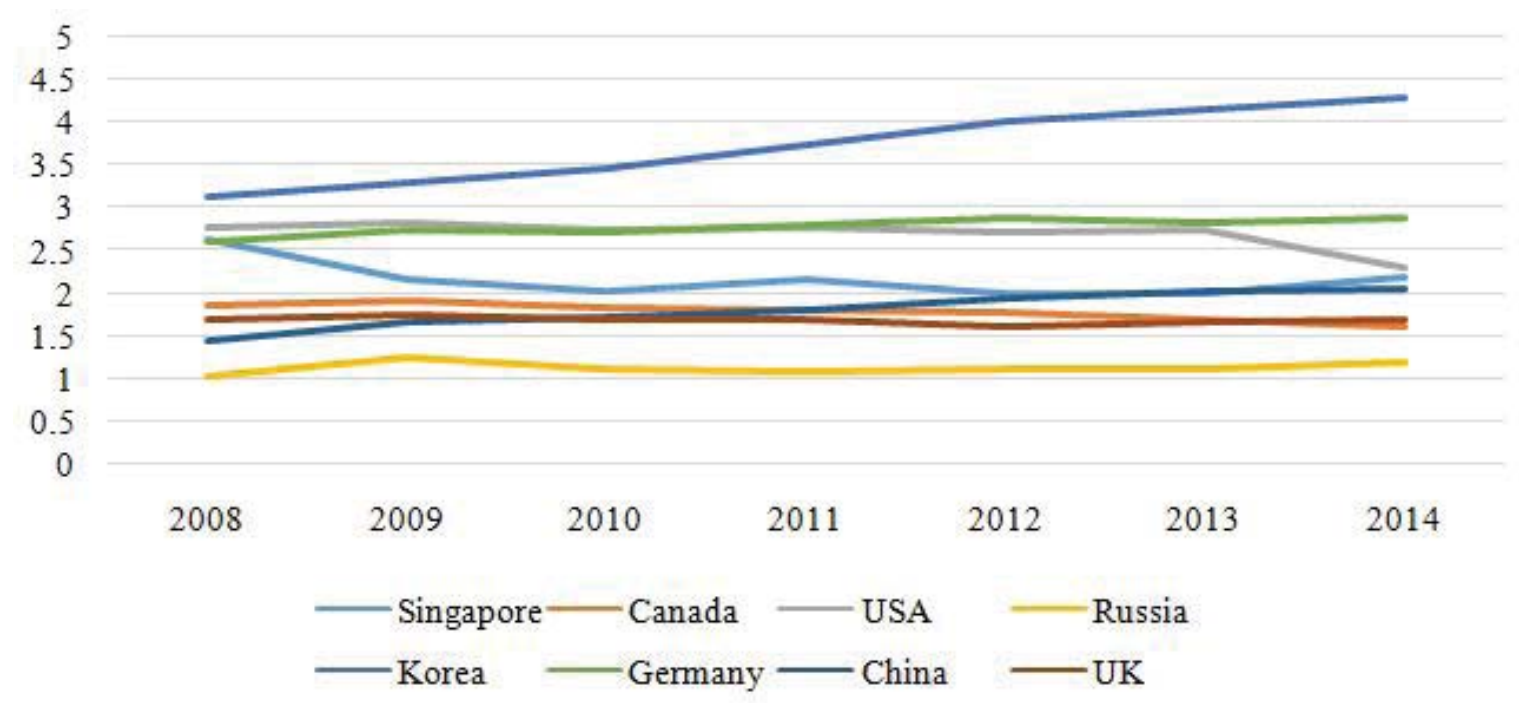

Figure 3: Gross domestic expenditures on R\&D in comparison with the Russian Federation (\% of GDP) [10]

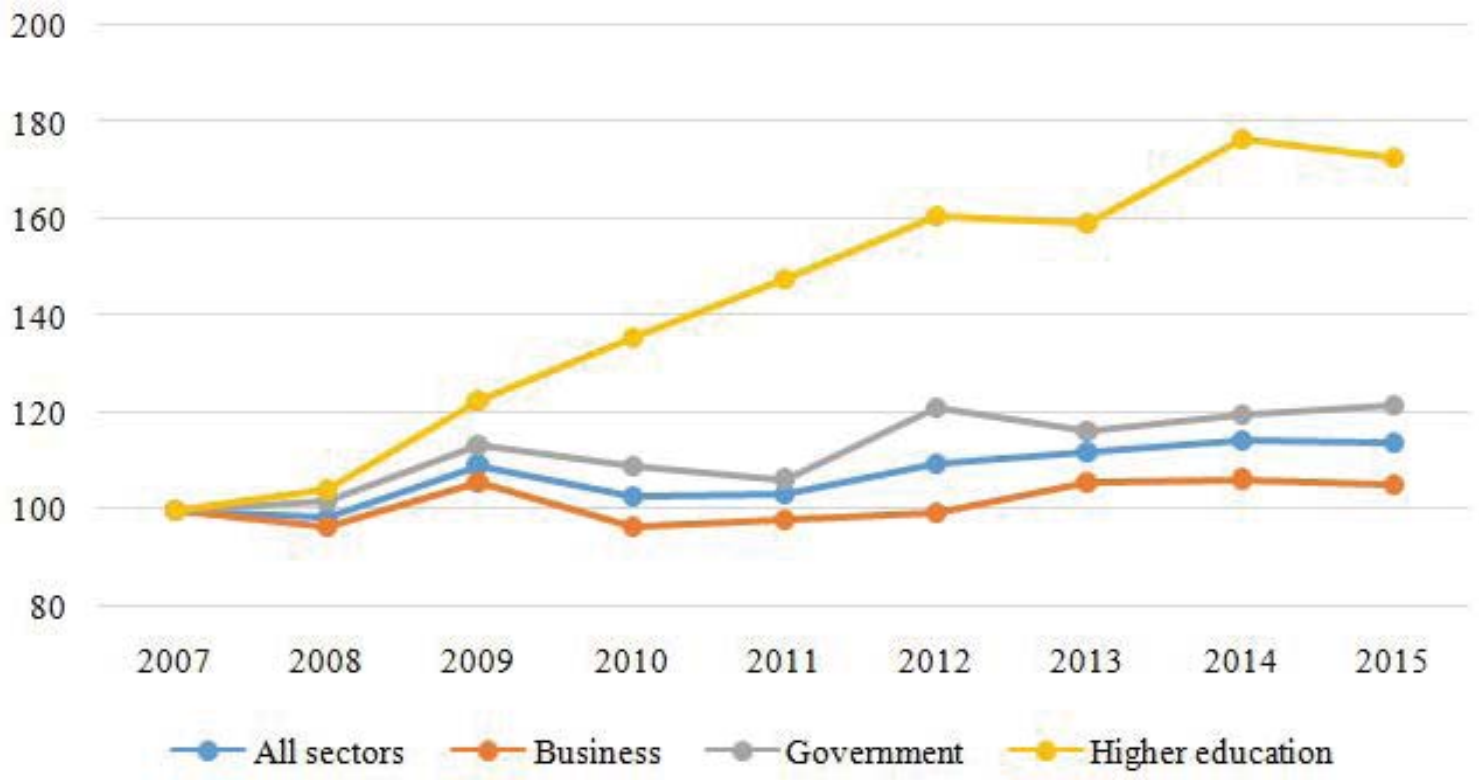

Figure 3: Gross domestic expenditures on R\&D in comparison with the Russian Federation (\% of GDP) [10] 
search and development in higher education has almost doubled (Figure 4) [11].

From the information above we can see the importance of developing university-industry interaction in Russian Federation. All the data shows the situation that without new technologies and knowledge exchange between the higher education instituters and industry the level of graduates and technologies in business will be at a lowest level.

\section{IMPORTANCE OF UNIVERSITY-INDUSTRY INTERACTION DEVELOPMENT}

The data demonstrates the necessity and importance of developing partnerships between the university and industry. The relevancy of university - business cooperation for universities is as follows:

- accelerate the process of innovation;

- receiving additional funding (other than the state and sharing the costs of research activities);

- availability of feedback from the industry and mentoring by industry and business;

- jobs for university graduates;

- availability of researchers working in enterprises and receiving newest information about the leading trends and market demands;

- elimination of risk and uncertainty due to inconsistency of inquiries of the university industry;

- availability of access to practical knowledge from the industry and research base development basis of the gained knowledge.

- The relevancy of university - business cooperation for business (industry) is as follows:

- prevention of additional infrastructure costs and hiring of specially trained personnel, or retraining "on-site";

- problems arising in companies solve by combining intellectual resources between industry and university (competencies and skills);

- the industry receives the best staff (talented graduates) on the basis of cooperation and knowledge of the university students' contingent;

- creating new opportunities and competitive advantages in connection with access to new research and start-up ideas;

- availability of access to the network of teachers, leading scientists and specialists;

- new opportunities in cooperation with other companies interested in the same university-based research and cost sharing;

- evening-out financial losses (according to the IUCRC program [12], every dollar invested in the partnership is used 40 times);

- availability of access to the latest research and development conducted by the scientific community;

- concentration of necessary competencies within the existing team of specialists, supplemented by university staff;

- elimination of difficulties in accessing external sources of research funding, which significantly reduces their cost;

- new opportunities for technological development in conditions of sanctions.

The need for cooperation between universities and industry is growing every day, which is confirmed by all the above facts.

\section{BARRIERS ON THE WAY OF UNIVERSITY- INDUSTRY INTERACTION}

However, despite the need to develop partnerships between these areas, there are barriers that are getting in the way of effective interaction (Table 2) [13].

These barriers are key barriers to the formation of a successful university-business partnership. Despite the

Table 2: Barriers in the university-industry interaction

\begin{tabular}{|l|l|}
\hline University & Industry \\
\hline Negotiations on intellectual rights and other contract
\end{tabular}
conductions are difficult to complete with a result that suits both sides. The process isn't transparent and takes a lot of time.

Lack of funding

Business and university work in different time contexts.

Lack of trust or understanding

Low overall level of business investment in research and development, including lack of absorbency

University indicators, $\quad$ Business focuses on including citations, short-term rather than determine the priority of long-term R\&D producing high-quality publications

Other pressure on grad days (teaching and research) limits resources for cooperation.

Cooperation experience isn't assessed as a part of progress in academic career.

Business finds a difficult to define academic partners or academic ability.

Lack of alignment of objectives: tensions between business and university needs / objectives.

Lack of time / resources for establishing cooperative networks or project development

Lack of understanding by business of the potential benefits of working with universities

The tension between the academic desire to publish research results and business problems regarding competition Other problems with financing (for example, compliance with the requirements of small and medium-sized businesses) 
many difficulties that exist in the modern world, the formats of university-business interaction have evolved and are currently being formed into five formats of possible partnerships.

\section{UNIVERSITIES-INDUSTRY INTERACTION FORMATS IN RUSSIA}

If we consider the evolutionary line of interaction formats between the university and industry, then one of the first classifications is presented by Santoro, M. and Chakrabarti A. (2001) and includes four types of interaction: [14]

1. supporting of research through the allocation of financial resources, the use of equipment, the creation of charity trust funds for the renovation of university laboratories and the provision of scholarships for the implementation of new promising projects;

2. conducting joint research on a contract basis with the participation of researchers or staff engaged in consulting services, as well as the establishment of research groups specifically designed to solve business problems:

3. knowledge transfer through formal and informal interaction, cooperation in the field of education, curriculum development and staff exchange;

4. technology transfer is focused on solving a specific business problem when the university is engaged in research and development, being an expert, evaluating and promoting the technologies necessary for the market (patents, licenses).

Later, Davey, T., Baaken, T., Galan Muros, V. and Meerman, A. (2011) [15] presented an expanded list of interaction formats, which comprised the following items:

1. joint scientific research;

2. commercialization of R\&D results;

3. mobility of students and employees - the dissemination of knowledge and technology through the exchange of students and teaching staff between universities and enterprises;

4. development of joint training programs, including courses, special guest lectures and seminars;

5. life-long learning and development of competences and skills, including extended education, training and mentoring;

6. entrepreneurship - active involvement of universities in the creation of new enterprises and development of entrepreneurial thinking among students and scientists as a result of interaction with business structures;

7. management - scientists from universities participating in companies' decision-making and form the side of management positions; on the other hand, business representatives participate in the management of university departments, and so on.

In 2017, this list was optimized and clustered by Paola Rücker Schaeffer, Andréia Cristina Dullius, Rodrigo Maldonado Rodrigues, Paulo Antonio Zawislak, (2017) [16] and represents five key clusters through which mutually beneficial cooperation takes place. These formats of cooperation applicable to Russian system with some addictions mentioned below:

1. Education-oriented: provision of educational services on a short-term or long-term basis. This form of interaction doesn't imply long-term cooperation and can be in the form of short-term training both from the university and from the industry. (Figure 5)

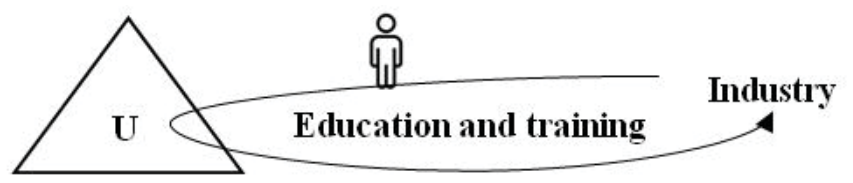

Figure 5: Partnership based on the provision of educational services

2. Intellectual property oriented: this type is granting of universities an object of intellectual property for use and receiving certain benefits for it. An example of such interaction is access to academic documents or the acquisition of patents. Patents may be included in this classification provided that the industry or the customer of the patent hasn't participated in its development (Figure 6).

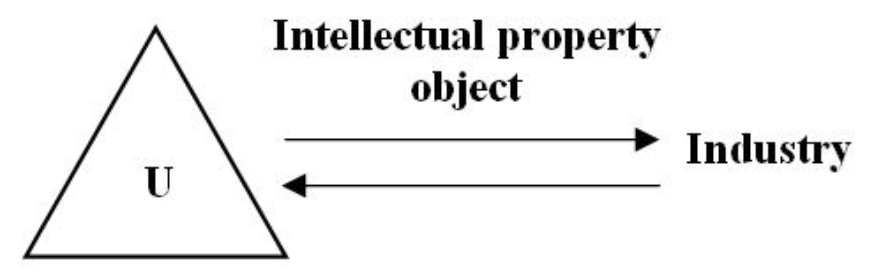

Figure 6: Partnership based on the provision of intellectual property for use

3. Service-oriented: is the provision of services and / or equipment for use on terms of partnerships (Figure 7). Examples of such interactions include services such as technical advice and the use of funds provided by the partner, including laboratories and test materials.

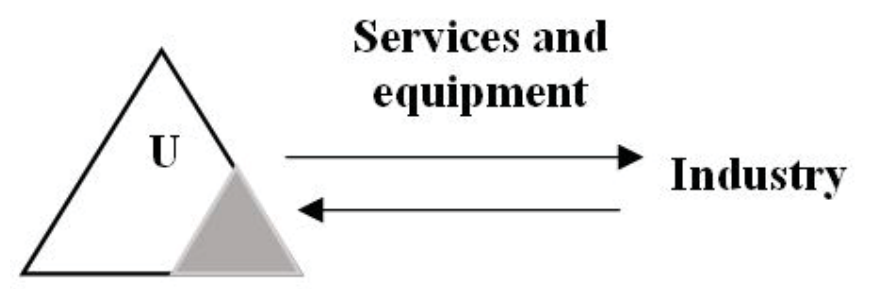

Figure 7: Partnership based on the provision of
services and equipment

4. Development-oriented: these are interactions aimed at joint technological development (Figure 8). The university unites with industry/business to solve any technological problem important for both sides. In this type of interaction, participants are active, even when the results are used only in the short term.

5. Research-oriented: this type of interaction is the most difficult. All participants must be active in R\&D process (Figure 9). As a rule, it is based on longterm cooperation, which includes the creation of a 


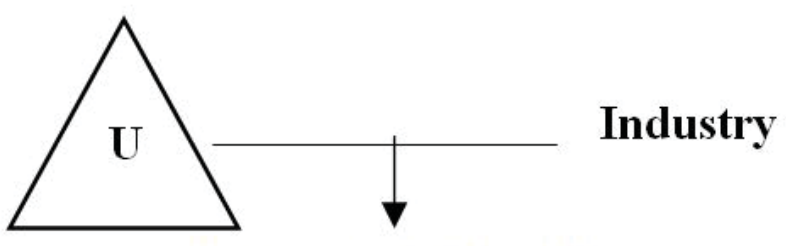

Technological problem

Figure 8: Partnership, aimed at solving the technological problem

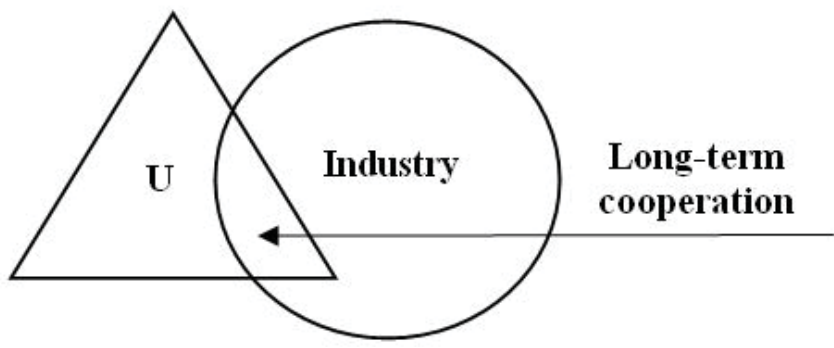

Figure 9: Partnership based on the research base development

research base, the formation of new knowledge and the implementation of joint projects. This format of interaction implies bi-directional flows of knowledge and information between universities and industries, as well as collective responsibility for the result.

The presented clusters of interaction formats are relevant for the majority of Russian universities, however, only a small amount is used in practice in the Russian Federation.

\section{DISCUSSION}

Nowadays, the world is at the point of bifurcation, which determines the choice of development vectors, changes and opportunities for both universities and the industrial sector.

Partnership in the modern world is characterized by the following features:

- Cooperation is carried out between "non-obvious partners".

- There are often dozens, even hundreds, of collaborating partners.

- Collaboration is often provided by digital and other rapidly evolving technologies, such as cloud computing in biotechnology. Digital technology can also allow "convergence" in different industries to create truly new solutions.

- There are many levels and ways of cooperation, ranging from strategic alliances and joint ventures to "intra-entrepreneurship."

- Players and relationships are developing quickly.

- There is availability of open source data and a culture of information sharing.

In the world of such partnership rules we mention that universities need to develop formats of university-indus- try integration to the current challenges. Simultaneously, universities are a very unchangeable organizational structure and novelty is always danger for it. This situation pushes universities to think about their future without additional government funding and the existence in the world of competitiveness.

This research shows the historical material about university-industry interaction which demonstrates some periods when cooperation decay and the next period needs to start over. However, it leads to a great gap in university-industry partnership in Russian from the other world. The material above demonstrates that the nature of partnership is changing and universities can't live in the same conditions for a long time. With the help of cooperation formats, we can suggest different models of cooperation for various of universities types.

As for business sphere, the need of cooperation is growing but the ability to invest in R\&D research is decreasing. In Russia corporations have their own laboratories and corporate universities and they have no need to cooperate with universities. Small and mid-size business stay in another position when they have no much money for R\&D and they try to do as much as they can without cooperation with universities. In these conditions it's very hard for universities to choose the right way in partnership and become more attractive for business and industry [23].

Both - universities and industry -have their own interest in cooperation and barriers, but what they need to do is to achieve their main goal - to overcome all hedges and find the most convenient way of integration.

\section{IMPLICATIONS FOR THEORY, PRACTICE AND FUTURE RESEARCH}

This article can serve as an analytical material for university management and researchers who want to develop their relations with the industrial sector in accordance with the needs of the regions, as well as understand the situation in this area and create favorable conditions for the development of partnerships (for example, the entrepreneurial sphere). The key limitation of this study is the impossibility of providing the testing results of the screw model relative to the universities in Russia due to the insufficient refinement of the model. This research should be continued as part of the finalization of the screw model and its formation and development in the field of interaction between universities and industry. The results of the research presented in this article can serve as an aid to the industrial sector development in regions through building the interaction "university-industry", taking into account possible barriers and priority areas of development.

Particular value this article demonstrates for universities that have the necessary resources (material, intellectual, technical) and their main goal is to establish the university as a driver for the development of the territory on which they are located. The originality of this article is a detailed analysis of the interaction of universities and 
industry, identifying the need for this partnership, considering the key barriers and ways of possible cooperation. The presented topic has not been studied in detail so far, which confirms the relevance of this research.

\section{REFERENCES}

1. Saprykin D. L. «Zolotoi vek» otechestvennoi nauki i tekhniki i «klassicheskaya» kontseptsiya inzhenernogo obrazovaniya . D.L. Saprykin . Voprosy istorii estestvoznaniya i tekhniki. 2013. № 1. S. 28-66.

2. Sheregi F.E., Strikhanov M.N. Nauka v Rossii: sotsiologicheskii analiz. M.: TsSP, 2006. 456 s Elektronnyi resurs: http://www.sheregi.ru/files/Strihanov_001_456.pdf (accessed: 13.02.2018 g.)

3. «Monitoring ehkonomicheskoj situacii v Rossii» https://www.ranepa.ru/images/docs/monitoring/2-63-rus-2018.pdf (accessed: 24.04.2018)

4. Kvalificirovannaya migraciya $v$ Rossii: balans poter' i priobretenij https://www.ranepa.ru/images/ docs/monitoring/2018_1-62_January.pdf (accessed: 25.04.2018)

5. Federal'naya sluzhba gosudarstvennoj statistiki http://www.gks.ru (accessed: 18.04.2018)

6. Rossiya 2025: ot kadrov k talantam http://d-russia. ru/wp-content/uploads/2017/11/Skills_Outline_web_ tcm26-175469.pdf (accessed: 25.04.2018)

7. «Monitoring ehkonomicheskoj situacii v Rossii» https://www.ranepa.ru/images/docs/monitoring/2018_1-62_January.pdf (accessed: 24.04.2018)

8. World Bank http://data.worldbank.org/indicator/GB.XPD.RSDV.GD.ZS? end=2014\&locations $=C N \&$ start=2008 (accessed: 19.04 .2018 )

9. Federal'naya sluzhba gosudarstvennoj statistiki http://www.gks.ru (accessed: 18.04.2018)

10. OECD http://www.oecd.org/sti/msti.htm (accessed: 22.04.2018)

11. Summary report of the 2015 UIS Innovation Data Collection //UNESCO institute for statistics //Information paper №37 March 2017

12. Industry - University Cooperative Research Program http://iucrc.org/ (accessed: 23.04.2018)

13. Business-university research collaboration: dowling review - final report http://www.gov.uk/government/ publications/business-university-research-collaborations-dowling-review-final-report (accessed: 26.04.2018)

14. Santoro, M. and Chakrabarti A. (2001), Firm Size and Technology Centrality in Industry-University Interactions, MIT IPC Working Paper IPC-01-001

15. Davey, T., Baaken, T., Galan Muros, V. and Meerman, A. (2011), The State of European University-Business Cooperation. Part of the DG Education and Culture Study on the Cooperation between Higher Education Institutions and Public and Private Organisations in Europe
16. Paola Rücker Schaeffer, Andréia Cristina Dullius, Rodrigo Maldonado Rodrigues, Paulo Antonio Zawislak, (2017) "Searching to bridge the gaps: a new typology of university-industry interaction", Academia Revista Latinoamericana de Administración, Vol. 30 Issue: 4, pp.459-473, https://doi.org/10.1108/ARLA05-2016-0148

17. Carayannis E., Grigoroudis E. (2016) Quadruple Innovation Helix and Smart Specialization: Knowledge Production and National Competitiveness. Foresight and STI Governance, vol. 10, no 1, pp. 31-42. DOI: 10.17323/1995-459x.2016.1.31.42

18. Lars Frølund, Fiona Murray, and Max Riedel (2018) " Developing Successful Strategic Partnerships With Universities" https://sloanreview.mit.edu/article/developing-successful-strategic-partnerships-with-universities/

19. Michaël Kolk, Rick Eagar, Charles Boulton, Carlos Mira, (2018) "How hyper-collaboration accelerates ecosystem innovation", Strategy \& Leadership, Vol. 46 Issue: 1, pp.23-29, https://doi.org/10.1108/SL-102017-0100

20. Obshchie podkhody k formirovaniyu tsifrovogo prostranstva Evraziiskogo ekonomicheskogo soyuza v perspektive do 2030 goda. Podgotovleno EEK v ramkakh vyrabotki predlozhenii po formirovaniyu tsifrovogo prostranstva EAES Elektronnyi resurs: http://www.eurasiancommission. org/ru/act/dmi/workgroup/materials/Documents/ Общие\%20подходы\%20к\%20формированию\%20 ЦП\%20.pdf (accessed: 12.03.2018)

21. Sukhinov A. I., Ugnich E. A. Malye innovatsionnye predpriyatiya pri universitetakh// Universitetskoe upravlenie: praktika i analiz, Tom 21, № 4, 2017, str. 98-106

22. G.Itskovits Troinaya spirat'. Universitety-predpriyatiya-gosudarstvo. Innovatsii v deistvii. Genri Itskovits; per. s angl. pod red. A.F. Uvarova. Tomsk: Izdvo Tomsk. gos. un-ta sistem upr. i radioelektroniki, 2010. 238 s., str.37

23. Carayannis E., Grigoroudis E. (2016) Quadruple Innovation Helix and Smart Specialization: Knowledge Production and National Competitiveness. Foresight and STI Governance, vol. 10, no 1, pp. 31-42. DOI: 10.17323/1995-459x.2016.1.31.42 https://www. hse.ru/data/2016/04/14/1129617631/3-Carayannis-31-42.pdf (accessed: 27.02.2018)

24. Ovchinnikova, N., Ovchinnikova, O., Kolmykova, T., \& Bredikhin, V. [2018]. New generation of regional universities in Russia. Journal of Applied Engineering Science, 16(1), 132-141.

Paper submitted: 22.05.2019.

Paper accepted: 14.06.2019.

This is an open access article distributed under the CC $B Y-N C-N D 4.0$ terms and conditions. 